\title{
Isohericenone, a new cytotoxic isoindolinone alkaloid from Hericium erinaceum
}

\author{
Ki Hyun Kim ${ }^{1,4}$, Hyung Jun $\mathrm{Noh}^{2,4}$, Sang Un Choi ${ }^{3}$ and Kang Ro Lee ${ }^{1}$ \\ The Journal of Antibiotics (2012) 65, 575-577; doi:10.1038/ja.2012.65; published online 25 July 2012
}

Keywords: cytotoxicity; Hericiaceae; Hericium erinaceum; isohericenone

In our continuing search for structurally interesting and cytotoxic metabolites from Korean wild mushrooms, ${ }^{1-5}$ we have collected scores of Korean mushroom species annually and evaluated their $\mathrm{MeOH}$ extracts for their antitumor activity in our screening test. Among the collected wild mushrooms, the extract of Hericium erinaceum showed significant cytotoxicity against A549, SK-OV-3, SK-MEL-2 and HCT15 cell lines using a sulforhodamine B (SRB) bioassay. This mushroom H. erinaceum (Yamabushitake in Japanese) belonging to the family Hericiaceae is widely known as edible mushroom that grows on dead trunks of hard woods in Korea, Japan, China and Europe. This mushroom has been used as a medicine for the treatment of dyspepsia, gastric ulcer and enervation in traditional Chinese medicine for a long time. ${ }^{6}$ This medicinal mushroom is a rich source of unique metabolites. Chemical components of this mushroom have been reported to have hericenones $\mathrm{A}$ and $\mathrm{B}$ as cytotoxic constituents, ${ }^{7}$ hericenones $\mathrm{C}, \mathrm{D}$ and $\mathrm{E}$ as stimulators of nerve growth factor synthesis, ${ }^{8}$ hericenone $\mathrm{J}$ as an endoplasmic reticulum stress-suppressive substance, ${ }^{9}$ hericerin as a pollen growth inhibitor ${ }^{10}$ and antitumor-active polysaccharides ${ }^{11}$ as the bioactive components. A bioassay-guided fractionation and chemical investigation of its $\mathrm{MeOH}$ extract resulted in the isolation of a new isoindolinone alkaloid named isohericenone (1), together with nine known compounds, namely isohericerin $(2),{ }^{6}$ erinacerin B (3), ${ }^{12}$ hericenone A (4), ${ }^{7}$ hericenone J (5), ${ }^{9}$ 3,4-dihydro-5-methoxy-2methyl-2-(4'-methyl-2'-oxo-3'-pentenyl)-9(7H)-oxo-2H-furo[3,4-h] benzopyran (6), ${ }^{13}$ erinacerin A $(7),{ }^{12}$ hericenone $\mathrm{F}(\mathbf{8}),{ }^{14}$ hericenone $\mathrm{D}(\mathbf{9})^{8}$ and hericenone $\mathrm{E}(\mathbf{1 0})^{8}$ (Figure 1). Here, we describe the isolation and structural elucidation of (1) as well as the cytotoxic activities of compounds $\mathbf{1 - 1 0}$.

The half dried fruiting bodies of $H$. erinaceum $(5.0 \mathrm{~kg})$ were extracted with $80 \%$ aqueous $\mathrm{MeOH}$ twice at room temperature and then filtered. The filtrate was evaporated under vacuum to afford a $\mathrm{MeOH}$ extract $(500 \mathrm{~g})$, which was partitioned with hexane, $\mathrm{CH}_{2} \mathrm{Cl}_{2}$, EtOAc and $n-\mathrm{BuOH}$ subsequently with $\mathrm{H}_{2} \mathrm{O}$, yielding hexane $(63.3 \mathrm{~g})$,
$\mathrm{CH}_{2} \mathrm{Cl}_{2}(4.5 \mathrm{~g})$, EtOAc (2.0 g) and $n-\mathrm{BuOH}$ fractions (17.5 g). Each fraction was evaluated for its cytotoxicity against A549, SK-OV-3, SKMEL-2 and HCT-15 cell lines using a SRB bioassay. We selected the hexane-soluble and $\mathrm{CH}_{2} \mathrm{Cl}_{2}$-soluble fractions for the current phytochemical investigation, because the $\mathrm{CH}_{2} \mathrm{Cl}_{2}$-soluble fraction was the most active and hexane-soluble fraction also had significant cytotoxicity against the tested tumor cell lines. The active hexane-soluble fraction $(60 \mathrm{~g})$ was separated on a silica gel column with a gradient solvent system of hexane-EtOAc $(50: 1-1: 1)$ to give five fractions $(\mathrm{H} 1-\mathrm{H} 5)$. Fraction $\mathrm{H} 1$ (11 g) was separated on a $\mathrm{RP}_{-} \mathrm{C}_{18}$ silica gel column using a gradient solvent of increasing $\mathrm{MeOH}$ in $\mathrm{H}_{2} \mathrm{O}$ from 10 to $100 \%$ to give three subfractions (H11-H13). Fraction H13 $(5 \mathrm{~g})$ was separated twice on a $\mathrm{RP}-\mathrm{C}_{18}$ silica gel column with a gradient solvent system of $\mathrm{MeOH}-\mathrm{H}_{2} \mathrm{O}(2: 3-7: 3)$ and then purified by RP$\mathrm{C}_{18}$ preparative HPLC (Econosil RP-18 $10 \mu$ column (Alltech, Nicholasville, KY, USA), $250 \times 10 \mathrm{~mm}^{2}$ ) using a solvent of $\mathrm{MeOH}-$ $\mathrm{H}_{2} \mathrm{O}(1: 1)$ to yield compound (5) (9 mg). Fraction $\mathrm{H} 2$ (12 g) was subjected to repeated $\mathrm{RP}-\mathrm{C}_{18}$ silica gel column separation using a gradient solvent system of $\mathrm{MeOH}-\mathrm{H}_{2} \mathrm{O}(1: 1-7: 3)$ and then purified by $\mathrm{RP}^{-\mathrm{C}_{18}}$ preparative HPLC $(60 \% \mathrm{MeOH})$ to afford compound (6) $(4 \mathrm{mg})$. Fraction $\mathrm{H} 5(10 \mathrm{~g})$ was separated on a $\mathrm{RP}^{-\mathrm{C}_{18}}$ silica gel column using a gradient solvent of increasing $\mathrm{MeOH}$ in $\mathrm{H}_{2} \mathrm{O}$ from 10 to $100 \%$ to give three subfractions (H51-H53). Fraction H51 (1 g) was isolated using repeated $\mathrm{RP}^{-\mathrm{C}_{18}}$ silica gel column separation with a gradient solvent system of $\mathrm{MeOH}-\mathrm{H}_{2} \mathrm{O}(2: 3-7: 3)$ and then purified by $\mathrm{RP}_{-} \mathrm{C}_{18}$ preparative HPLC $(60 \% \mathrm{MeOH})$ to give compound (9) (38 mg). Fraction H53 ( $1 \mathrm{~g}$ ) was subjected to repeated $\mathrm{RP}^{-\mathrm{C}_{18}}$ silica gel column separation using a gradient solvent system of $\mathrm{MeOH}-\mathrm{H}_{2} \mathrm{O}$ ( $1: 1-7: 3)$ and then purified by $\mathrm{RP}^{-\mathrm{C}_{18}}$ preparative HPLC $(50 \%$ $\mathrm{MeOH})$ to afford compound (8) $(36 \mathrm{mg})$. The most active $\mathrm{CH}_{2} \mathrm{Cl}_{2}$ soluble fraction $(4 \mathrm{~g})$ was separated on a silica gel column with a gradient solvent system of $\mathrm{CH}_{2} \mathrm{Cl}_{2}-\mathrm{MeOH}(50: 1-1: 1)$ to yield five fractions (C1-C5). Fraction C2 (1 g) was separated on a $\mathrm{RP}^{-\mathrm{C}_{18}}$ silica gel column using a gradient solvent of increasing $\mathrm{MeOH}$ in $\mathrm{H}_{2} \mathrm{O}$ from

\footnotetext{
${ }^{1}$ Natural Products Laboratory, School of Pharmacy, Sungkyunkwan University, Suwon, Korea; ${ }^{2}$ Department of Herbal Crop Research, National Institutes of Horticultural and Herbal Science, RDA, Eumseoung, Korea and ${ }^{3}$ Bio-organic Science Division, Pharmacology Research Center, Korea Research Institute of Chemical Technology, Teajeon, Korea ${ }^{4}$ These authors contributed equally to this work.

Correspondence: Professor Dr KR Lee, Natural Products Laboratory, School of Pharmacy, Sungkyunkwan University, 300 Chonchon-dong, Suwon 440-746, Korea.

E-mail: krlee@skku.ac.kr

Received 14 May 2012; revised 17 June 2012; accepted 3 July 2012; published online 25 July 2012
} 


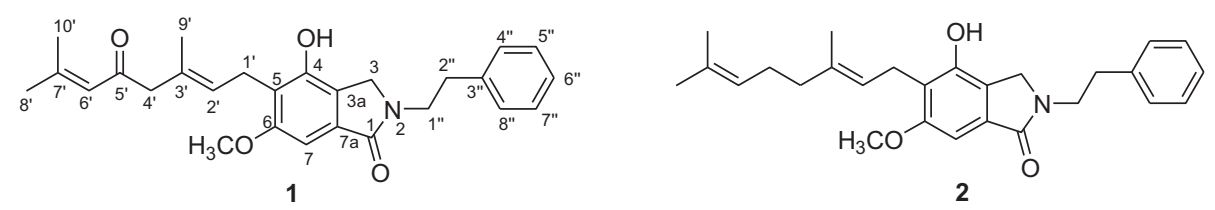<smiles>COc1cc2c(c(O)c1C/C=C(\C)C[C@H](O)C=C(C)C)COC2=O</smiles><smiles>COc1cc2c(c(O)c1C/C=C(\C)CC(=O)C=C(C)C)COC2=O</smiles><smiles>COc1cc2c(c(O)c1C/C=C(\C)CCC=C(C)C)C(=O)OC2</smiles><smiles>COc1cc2c(c3c1CCC(C)(CC(=O)C=C(C)C)O3)C(=O)OC2</smiles>

6<smiles>[R]OCc1cc(OC)c(C/C=C(\C)CC(=O)C=C(C)C)c(O)c1C=O</smiles><smiles>COc1cc2c(c3c1CC(C)(CC(=O)C=C(C)C)O3)CN(CCc1ccccc1)C2=O</smiles><smiles>CCCCC(=O)OCc1cc(OC)c2c(c1C=O)OC(C)(CC(=O)C=C(C)C)CC2</smiles><smiles>[R]OC(C)=O</smiles>

Figure 1 Structures of compounds 1-10.

10 to $100 \%$ to furnish five subfractions (C21-C25). Fraction C24 $(200 \mathrm{mg})$ was subjected to passage over a $\mathrm{RP}^{-\mathrm{C}_{18}}$ silica gel column using a gradient solvent system of $\mathrm{MeOH}-\mathrm{H}_{2} \mathrm{O}(1: 1-7: 3)$ and then purified by $\mathrm{RP}_{18} \mathrm{C}_{18}$ preparative HPLC $(50 \% \mathrm{MeOH})$ to give compounds (1) (16 mg), (3) (4 mg), (4) (3 mg), and (7) (9 mg). Compounds (2) $(50 \mathrm{mg})$ and $(\mathbf{1 0})(7 \mathrm{mg})$ were isolated from fraction C5 (900 mg) using repeated $\mathrm{RP}_{-} \mathrm{C}_{18}$ silica gel column separation with a gradient solvent system of $\mathrm{MeOH}-\mathrm{H}_{2} \mathrm{O}(2: 3-7: 3)$ and purification with $\mathrm{RP}_{18} \mathrm{C}_{18}$ preparative HPLC $(60 \% \mathrm{MeOH})$.

Compound (1) was isolated as a colorless gum. Its molecular formula was determined as $\mathrm{C}_{27} \mathrm{H}_{31} \mathrm{O}_{4} \mathrm{~N}$ from the $[\mathrm{M}+\mathrm{Na}]^{+}$peak at $m / z$ 456.2155 (calculated for $\mathrm{C}_{27} \mathrm{H}_{31} \mathrm{O}_{4} \mathrm{NNa}, 456.2151$ ) in the positive-ion high resolution (HR)-ESI-MS spectrum. The IR spectrum of (1) showed the presence of a hydroxyl group $\left(3357 \mathrm{~cm}^{-1}\right)$, a $\gamma$-lactam $\left(1701 \mathrm{~cm}^{-1}\right)$, an $\alpha, \beta$-unsaturated ketone $\left(1661 \mathrm{~cm}^{-1}\right)$ and phenyl groups $\left(1593 \mathrm{~cm}^{-1}\right)$. The physico-chemical properties of (1) are summarized in Supplementary Information. The ${ }^{1} \mathrm{H}-$ and ${ }^{13} \mathrm{C}-$ NMR spectral data of (1) are shown in Table 1.

The ${ }^{1} \mathrm{H}$ - and ${ }^{13} \mathrm{C}-\mathrm{NMR}$ spectra (Table 1 ) of (1) were very similar to those of $(2),{ }^{6}$ with an apparent difference being the presence of signal attributable to an $\alpha, \beta$-unsaturated ketone at $\delta_{\mathrm{C}} 200.9$ in (1). The shifted signals for C- $3^{\prime}$ at $\delta_{\mathrm{C}} 129.4$, for C- $4^{\prime}$ at $\delta_{\mathrm{C}} 54.9$ and for C- $7^{\prime}$ at $\delta_{\mathrm{C}} 156.3$ were clearly observed in the ${ }^{13} \mathrm{C}-\mathrm{NMR}$ spectrum of (1), compared with those of corresponding ones in (2), suggesting that the $\alpha, \beta$-unsaturated ketone in (1) was located at C-5 in combination with the absence of the signal for methylene carbon $\left(\delta_{\mathrm{C}} 26.5\right)$ at $\mathrm{C}-5^{\prime}$ of (2). This partial structure was confirmed by the identical ${ }^{13} \mathrm{C}-\mathrm{NMR}$ chemical shifts of the partial structure $\left(\mathrm{C}-1^{\prime}-\mathrm{C}-10^{\prime}\right)$ of (1) with those of 4, 9 and 10, , $^{7,8}$ and HMQC and HMBC correlations of (1) (Figure 2). The core structure of this molecule, isoindoline-1-one substructure, was unambiguously confirmed by $\mathrm{HMBC}$ correlations from $\mathrm{H}-7$ to $\mathrm{C}-1$ and from $\mathrm{H}-3$ to $\mathrm{C}-4$ (Figure 2). The gross structure
Table $1{ }^{1} \mathrm{H}$ - and ${ }^{13} \mathrm{C}$-NMR data of compounds (1) and (2)

\begin{tabular}{|c|c|c|c|c|}
\hline \multirow[b]{2}{*}{ Position } & \multicolumn{3}{|c|}{1} & \multirow{2}{*}{$\begin{array}{c}2 \\
\delta_{C}\end{array}$} \\
\hline & $\delta_{C}$ & $\delta_{H}$ & $H M B C$ & \\
\hline 1 & $169.9 \mathrm{~s}$ & & & $169.3 \mathrm{~s}$ \\
\hline 3 & $48.6 \mathrm{t}$ & $4.17(\mathrm{~s})$ & C-1, 3a, 4, 7a, 1" & $48.5 \mathrm{t}$ \\
\hline $3 a$ & $121.2 \mathrm{~s}$ & & & $121.3 \mathrm{~s}$ \\
\hline 4 & $150.1 \mathrm{~s}$ & & & $150.6 \mathrm{~s}$ \\
\hline 5 & $120.7 \mathrm{~s}$ & & & $119.4 \mathrm{~s}$ \\
\hline 6 & $159.3 \mathrm{~s}$ & & & $158.8 \mathrm{~s}$ \\
\hline 7 & $96.5 \mathrm{~d}$ & $6.86(\mathrm{~s})$ & $\mathrm{C}-1,3 \mathrm{a}, 5,6,7 \mathrm{a}$ & $97.8 \mathrm{~d}$ \\
\hline $7 a$ & $131.1 \mathrm{~s}$ & & & $132.0 \mathrm{~s}$ \\
\hline $1^{\prime}$ & $22.5 \mathrm{t}$ & $3.45(d, 7.5)$ & $C-4,5,6,2^{\prime}, 3^{\prime}$ & $23.0 \mathrm{t}$ \\
\hline $2^{\prime}$ & $127.3 \mathrm{~d}$ & $5.31(t, 7.5)$ & $C-5,1^{\prime}, 3^{\prime}, 4^{\prime}, 9^{\prime}$ & $121.5 \mathrm{~d}$ \\
\hline $3^{\prime}$ & $129.4 \mathrm{~s}$ & & & $138.8 \mathrm{~s}$ \\
\hline $4^{\prime}$ & $54.9 \mathrm{t}$ & 2.99 (s) & $C-2^{\prime}, 3^{\prime}, 5^{\prime}, 6^{\prime}, 9^{\prime}$ & $39.9 t$ \\
\hline $5^{\prime}$ & $200.9 \mathrm{~s}$ & & & $26.5 \mathrm{t}$ \\
\hline $6^{\prime}$ & $122.6 \mathrm{~d}$ & $6.13(\mathrm{~s})$ & $C-4^{\prime}, 5^{\prime}, 7^{\prime}, 8^{\prime}, 10^{\prime}$ & $124.0 \mathrm{~d}$ \\
\hline $7^{\prime}$ & $156.3 \mathrm{~s}$ & & & $132.1 \mathrm{~s}$ \\
\hline $8^{\prime}$ & $26.5 \mathrm{q}$ & $1.81(\mathrm{~s})$ & $C-6^{\prime}, 7^{\prime}, 10^{\prime}$ & $25.8 \mathrm{q}$ \\
\hline $9^{\prime}$ & $15.4 \mathrm{q}$ & $1.74(\mathrm{~s})$ & $C-2^{\prime}, 3^{\prime}, 4^{\prime}$ & $16.3 \mathrm{q}$ \\
\hline $10^{\prime}$ & $19.6 q$ & $2.07(\mathrm{~s})$ & $C-6^{\prime}, 7^{\prime}, 8^{\prime}$ & $17.8 \mathrm{q}$ \\
\hline $1^{\prime \prime}$ & $44.2 \mathrm{t}$ & $3.84(t, 7.5)$ & $C-1,3,2^{\prime \prime}, 3^{\prime \prime}$ & $44.2 \mathrm{t}$ \\
\hline $2^{\prime \prime}$ & $34.4 \mathrm{t}$ & $2.97(t, 7.5)$ & $C-1^{\prime \prime}, 3^{\prime \prime}, 4^{\prime \prime}, 8^{\prime \prime}$ & $35.0 \mathrm{t}$ \\
\hline $3^{\prime \prime}$ & $138.9 \mathrm{~s}$ & & & $138.8 \mathrm{~s}$ \\
\hline $4^{\prime \prime}, 8^{\prime \prime}$ & $128.5 \mathrm{~d}$ & $7.24(\mathrm{~m})$ & $\mathrm{C}-2^{\prime \prime}, 4^{\prime \prime}, 6^{\prime \prime}, 8^{\prime \prime}$ & $128.8 d$ \\
\hline $5^{\prime \prime}, 7^{\prime \prime}$ & $128.4 \mathrm{~d}$ & $7.26(\mathrm{~m})$ & $\mathrm{C}-3^{\prime \prime}, 5^{\prime \prime}, 7^{\prime \prime}$ & $128.7 \mathrm{~d}$ \\
\hline $6^{\prime \prime}$ & $126.3 \mathrm{~d}$ & $7.21(\mathrm{~m})$ & C-4", $8^{\prime \prime}$ & $126.7 d$ \\
\hline $6-\mathrm{OCH}_{3}$ & $55.1 \mathrm{q}$ & $3.84(\mathrm{~s})$ & C-6 & $56.1 \mathrm{q}$ \\
\hline
\end{tabular}

Abbreviations: $d$, doublet; $\mathrm{m}$, multiplet; s, singlet; t, triplet.

NMR data were obtained in $500 \mathrm{MHz}$ for ${ }^{1} \mathrm{H}$ and $125 \mathrm{MHz}$ for ${ }^{13} \mathrm{C}$ in $\mathrm{CD}_{3} \mathrm{OD}$ for (1) and in $\mathrm{CDCl}_{3}$ for (2), and values in parentheses are coupling constants in $\mathrm{Hz}$. 


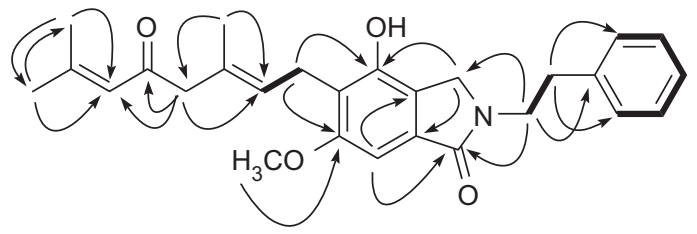

Figure $2{ }^{1} \mathrm{H}-{ }^{1} \mathrm{H}$ COSY (bold lines) correlations and key $\mathrm{HMBC}$ (arrows) of (1).

Table 2 Cytotoxic activities of compounds (1), (2), (6) and 7 isolated from $H$. erinaceum.

\begin{tabular}{lcccc}
\hline & \multicolumn{4}{c}{$I_{50}(\mu \mathrm{m})^{\mathrm{a}}$} \\
\cline { 2 - 5 } Compound & A549 & SK-OV-3 & SK-MEL-2 & HCT-15 \\
\hline $\mathbf{1}$ & 2.6 & 3.1 & 1.9 & 2.9 \\
$\mathbf{2}$ & 21 & 8.9 & 3.1 & 19 \\
$\mathbf{6}$ & 17 & 11 & 13 & 16 \\
$\mathbf{7}$ & 11 & 11 & 7.7 & 14 \\
Doxorubicin $^{\mathrm{b}}$ & 0.001 & 0.003 & 0.002 & 0.081 \\
\hline
\end{tabular}

${ }^{a} C_{50}$ value of compounds against cancer cell lines, defined as the concentration $(\mu \mathrm{m})$ that caused $50 \%$ inhibition of cell growth in vitro.

boxorubicin as a positive control.

of (1) was established by the HMBC experiment showing correlations from $\mathrm{H}-1^{\prime}$ to $\mathrm{C}-4$ and $\mathrm{C}-6$ and from $\mathrm{H}-1^{\prime \prime}$ to $\mathrm{C}-1$ and $\mathrm{C}-3$ (Figure 2). On the basis of the above data, the structure of (1) was assigned as shown in Figure 1 and the compound was named isohericenone.

Compound (2) was isolated as an amorphous powder with the molecular formula $\mathrm{C}_{27} \mathrm{H}_{33} \mathrm{O}_{3} \mathrm{~N}$, as determined by the HR-ESI-MS data at $m / z$ 442.2352 $[\mathrm{M}+\mathrm{Na}]^{+}$(calculated for $\mathrm{C}_{27} \mathrm{H}_{33} \mathrm{O}_{3} \mathrm{NNa}$, 442.2358). The full NMR assignments of (2) were performed by the analysis of the ${ }^{1} \mathrm{H}-{ }^{1} \mathrm{H}$ COSY, DEPT, HMQC and HMBC spectroscopic data (Table 1). According to the survey of literature, compound (2) was recently reported from this mushroom as isohericerin by Miyazawa et al. ${ }^{6}$ However, the spectral data of (2), particularly ${ }^{13} \mathrm{C}$ NMR data, were not completely matched with those of isohericerin. ${ }^{6}$ We suggest that the ${ }^{13} \mathrm{C}-\mathrm{NMR}$ data assignments at C-3a, C-7a and $\mathrm{C}-2^{\prime}$ of isohericerin should be corrected on the basis of our analysis of 2D-NMR data. It seems that the reported data of C-3a and C-7a should be changed with each other, similar with the case of isohericenone (1) and erinacerin A (7). ${ }^{12}$ Here, the corrected ${ }^{13} \mathrm{C}$ NMR data of isohericerin (2) are reported (Table 1).

Compounds 1-10 were evaluated for their antiproliferative activities against four human cancer cell lines, namely A549, SKOV-3, SK-MEL-2 and HCT-15 using the SRB bioassay. ${ }^{15}$ Compounds
(1), (2), (6) and (7) showed inhibitory activity against proliferation of the tested cell lines with $\mathrm{IC}_{50}$ values in the range of $1.9-21 \mu \mathrm{M}$ (Table 2). In particular, compound (1) exhibited the most potent cytotoxicity against A549, SK-OV-3, SK-MEL-2 and HCT-15 cell lines $\left(\mathrm{IC}_{50}: 2.6,3.1,1.9\right.$ and $2.9 \mu \mathrm{M}$, respectively) (Table 2 ). Compounds (1), (2), (6) and (7) may be promising for the development of effective drugs for various cancers. This study shows that these compounds can be considered as contributors to the antitumor activity of the mushroom $H$. erinaceum.

\section{ACKNOWLEDGEMENTS}

This research was supported by Basic Science Research Program through the National Research Foundation of Korea (NRF) funded by the Ministry of Education, Science and Technology (2012-0002237), and by the Rural Development Administration Grant by the Korean Government-JP007725. The authors thank Drs EJ Bang, SG Kim, and JJ Seo at the Korea Basic Science Institute for the NMR and MS spectra measurements.

1 Kim, K.H., Choi, S.U., Park, K.M., Seok, S.J. \& Lee, K.R. Cytotoxic constituents of Amanita subjunquillea. Arch. Pharm. Res. 31, 579-586 (2008).

2 Kim, K.H., Park, K.M., Choi, S.U. \& Lee, K.R. Macrolepiotin, a new indole alkaloid from Macrolepiota neomastoidea. J. Antibiot. 62, 335-338 (2009).

$3 \mathrm{Kim}, \mathrm{K} . \mathrm{H}$. et al. Russulfoen, a new cytotoxic marasmane sesquiterpene from Russula foetens. J. Antibiot. 63, 575-577 (2010).

$4 \mathrm{Kim}, \mathrm{K} . \mathrm{H}$. et al. Lactarane sesquiterpenoids from Lactarius subvellereus and their cytotoxicity. Bioorg. Med. Chem. Lett. 20, 5385-5388 (2010).

5 Kim, K.H., Choi, S.U. \& Lee, K.R. Gymnopilin K, a new cytotoxic gymnopilin from Gymnopilus spectabilis. J. Antibiot. 65, 135-137 (2012).

6 Miyazawa, M., Takahashi, T., Horibe, I. \& Ishikawa, R. Two new aromatic compounds and a new D-arabinitol ester from the mushroom Hericium erinaceum. Tetrahedron $6 \mathbf{8}$, 2007-2010 (2012).

7 Kawagishi, H., Ando, M. \& Mizuno, T. Hericenone A and B as cytotoxic principles from the mushroom Hericium erinaceum. Tetrahedron Lett. 31, 373-376 (1990).

8 Kawagishi, H. et al. Hericenone C, D and E, stimulators of nerve growth factor(NGF)synthesis, from the mushroom Hericium erinaceum. Tetrahedron Lett. 32, 4561-4564 (1991).

9 Ueda, K. et al. An endoplasmic reticulum (ER) stress-suppressive compound and its analogues from the mushroom Hericium erinaceum. Bioorg. Med. Chem. 16, 94679470 (2008).

10 Kimura, Y. et al. Hericerin, a new pollen growth inhibitor from the mushroom Hericium erinaceum. Agric. Biol. Chem. 55, 2673-2674 (1991).

11 Mizuno, T., Wasa, T., Ito, H., Suzuki, C. \& Ukai, N. Antitumor-active polysaccharides isolated from the fruiting body of Hericium erinaceum, an edible and medicinal mushroom called yamabushitake or houtou. Biosci. Biotechnol. Biochem. 56, 347-348 (1992).

12 Yaoita, Y., Danbara, K. \& Kikuchi, M. Two new aromatic compounds from Hericium erinaceum (BULL.: FR.) PERS. Chem. Pharm. Bull. 53, 1202-1203 (2005).

13 Yaoita, Y. \& Kikuchi, M. Constituents of mushrooms. XXV. Structures of new aromatic compounds from the fruiting bodies of Hericium erinaceum. Pers. J. Tohoku. Pharm. Uni. 52, 39-42 (2005).

14 Kawagishi, $\mathrm{H}$. et al. Chromans, hericenones F, G and $\mathrm{H}$ from the mushroom Hericium erinaceum. Phytochemistry 32, 175-178 (1993).

15 Skehan, P. et al. New colorimetric cytotoxicity assay for anticancer-drug screening. J. Natl Cancer Inst. 82, 1107-1112 (1990).

Supplementary Information accompanies the paper on The Journal of Antibiotics website (http://www.nature.com/ja) 